NASA Technical Memorandum 101374

\title{
Performance of Multimirror Quartzline Lamps in a High-Pressure, Underwater Environment
}

Howard A. Slater

Lewis Research Center

Cleveland, Ohio

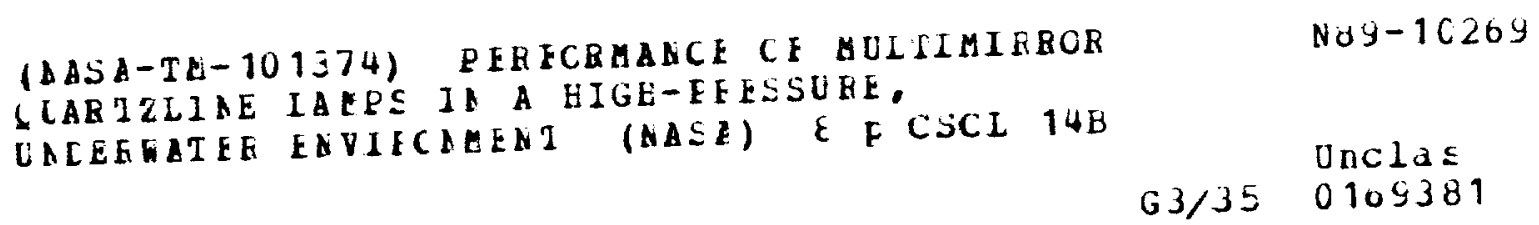

Prepared for the

32nd Annual International Symposium on Optical and Optoelectronic Applied Science and Engineering sponsored by the Society of Photo-Optical Instrumentation Engineers San Diego, California, August 14-19, 1988

\section{NMSA}


Perfornance of multimirror quartzline lamps in a high-pressure, underwater environment

Howard A. Slater

National Aeronautics and Space Administration

lewis Resear ch Center

cleveland, chio 44135

\section{ABSTF:ACT}

Multimirror Quartzline Lamps are extremely versatile and effective for nunconventional imaging requirements such as high-speed photo and video instrumentation and high-magnification imaging. The lamps versatility though, is not limited to conventional environments. Many research experiments and projects require a high-pressure environment. Continuous photographic data acquisition in a high-pressure vessel requi ces wall penetrations and creates design problems as well as potential failure sites. Underwater photography adds the extra consideration of a liquid. This report expandsi upon the basic research presented in "Performance of Multimi ror Quartzline Lamps in Hich-Pressure Environments" (NASA TM-83793, Ernie Walker and Howard Slater, 1984). The report provides information to professional Ernustrial. scientific, and technical photographers as well as research personnel on the survivability of lighting a multimirror quartz ine lamp in a nonconventional high-pressure underwater environment. Test results of lighted ELH $300 \mathrm{~W}$ multimirror quartzline lamps under high-pressure conditions are documented and general incormation on the lamp's intensity (foolcandle outpul), cone of lighl coverarge, approximale color temperature is provided. continuous lighting considerations in liquids are also discussed.

\section{INTRCDUCTION}

In 1984 basic research was conducted at NASA Lewis Research center's Photographic and pinting Branch on the "effectiveness and failise rates of various multimirror quartzline lamps under high-pressure conditions..." l The report, "Performance of Multimirror Quartzline Lamps in High-Pressure Environments", desiribed the survivability of various unlighted lamps in a high-pressure test environment. Pressures of up to 4400 psi were tested with no lamps imploding a dd only one-third showing signs of leakage. Lamps tested included General Electric's ELH, ?JI, ELC, and ENG. All lamps are from the Multimirror Quartaline family and "consist of $\exists$ small 2 -Pin Qualzline lamp permanently cemented in a dichroic coated one-piece, all glass reflector, wilh a series of special faceted finishes to optically control the bean pattern."2 Prior to this, testing had also been conducted on lighting in cryogenic and noncryogenic $t$ luids in a 1 atmenvironment.

"Lighting in Cryogenic and Noncryogenic Fluids", NASA Lewis technical film C260, demonstrated that ordinary and high-wattage tungsten lamps could be submerged in various cryogenic and noncryogenic fluids without any "perceptual changes in performance." In noncryogenic fluids a variety of heat transport modes were evident and the bulbs quickly reached thermal equilibrium. Lighting bulbs in cryogenic fluids was also satisfactorily 列 completed as initially a vapor fim formed around the bulb sum operation time of the bulbs in tested liquids was not determined. The film is available on loan.

\section{I:QUI PMLN"]"}

NASA Lewis's High pressure lest facility provided a convenient area to test the lamps up to $5000 \mathrm{psi}$. Figure 1 shows the layout of the test section utilized. In addition a current sensing transformer provided $20 \mathrm{mV}$ to a chart recorder when a lamp was lighted. This enabled an exact tract whenever the bulb was on and quick visual indication if the lamp failed. The lamps tested were General Electric's EIH NR-16 Q bulbs (Fjg. 2). Each lamp tested was held in the high-pressure chamber by a llamilculed support dovice (Fig. 3 ). City water

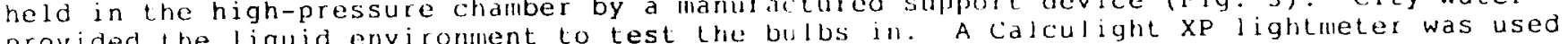
to calculate the lamps. footcandle output while a vai iac supplied the required voltage.

\section{PRR CEI)URE}

Footcandle and light cone measurements wert made at a distance of l ft in order to test the ELH's intensity and area of illumination. As in previous testing of the lamps, area of il lumination was determined from the center of the projected light to where incident light

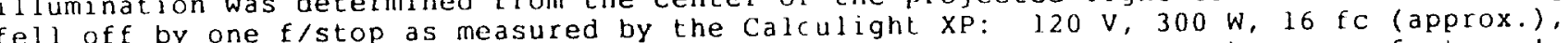
light cone of $6 \mathrm{in.}$ in dianeter, color tempercture $3350 \mathrm{~K}$. Tabie l shows inanufacturer's specifications for a variety of General Electi ic lamps. 
Each of $1 \mathrm{l}$ individual lamps was placed one at a $t$ ine in the support bracket and submerged in the pressure chamber. "l'he first 6 lamps were tested as follows. Pressure was increased to $3500 \mathrm{psi}$ and maintained for $30 \mathrm{sec}$ at which point the lamp was turned on. The initial starting pressure was based on previous survivability tests o[ the lamps at that level. Pressure and current levels were recorded on chart paper. After 30 sec at 3500 psi the lamp was turned of $f$ and pressure increased to 4000 psi. Pressure was again maintained for 30 sec and then the lamp was turned on for $30 \mathrm{sec}$. After $30 \mathrm{sec}$, the lamp is turned off and the pressure increased to $4500 \mathrm{psi}$. At this pressure level, lighted lamp time was successively increased with each lamp. Lamp l remained lit for $30 \mathrm{sec}$, lamp 2 for 1 min, lamp 3 for $2 \mathrm{~min}$, lamp 4 for $3 \mathrm{~min}$, etc. up to lamp 6 for $5 \mathrm{~min}$.

The next 5 lamps were tested to the maximum pressure of the system - 5000 psi. Testing up to 4000 psi was the same for these lamps as the others. At 4500 psi, the lamps were lit for only $30 \mathrm{sec}$. At $5000 \mathrm{psi}$ a total light time of $5 \mathrm{~min}$ was attempted. After each of the bulbs was tested, they were inspected visually for any damage or discoloration. Postpressure testing consisted of relighting the lamps in a normal environment to see if they were still functional. A Plexiglass chamber was used in case of explosion.

\section{RESUL'TS}

The compact design and high light outpul of the ELH lamp is ideal for many photographic and video assignments. Although a large enough sample was nol taken to inake statistical conclusions, the following results were observed. All of the lamps survived up to 4500 psi (Table 2). As the pressure was increased to 5000 psi two lamps failed while lighted. Both lamps 7 and 8 appeared to have had microscopic leaks and burried out. Upon visual inspection both lamps had small amounts of water in their inner lamp body with some black stains on the glass envelope. It appears that the leaks occurred thiough the conductor penetrations of the glass envelopes.

After all lamps had been tested in the high-pressure environment, they were relit in a regular fashion to see if any damage had occurred under testing. All lamps that survived the high-pressure test functioned normally during regular postpressure lighting.

A measure of conductivity showed $7000 \Omega$ of resistance in the city water. This compared with $70000 \Omega$ as measured with ionized water.

\section{CONCLUSIONS}

The General Electric line of Quartzline lamps are extremely versatile for use in a variety of photographic and video assignments. As the results of this report indicate, all the ELH Quartzline lamps functioned well up to 4500 psi with no protective housing and initially appear to be able to handle 5000 psi with some degree of success. Lighting in liquids becomes relatively easy when a few simple precautions are folluwed.

As mentioned in "Lighting in Cryogenic and Noncryogenic Fluids", the lamps should be totally submerged in a noncryogenic liquid prior to powering up in order to prevent "localized cooling and high thermal stresses" which may cause cerlain lamps to crack. When the lamp is totally submerged prior to lighting, thermal equilibi ium is easily achieved by the lamp and its environment. Additionally, lamps can be used in any liquid environment "provided thermal equilibrium can be achieved." This proves true not only for the rugged and compact LLH lamps tested but for regular household lamps as well.

The Multimirror Quartzline lamps continue to provide imaging specialists with an extremely versatile lighting tool under a variety of conditions. By knowing light output and area of coverage prior to installation. Iighting of hostile environments can be easily facilitated.

\section{ACKNOWLEDGMENTS}

Special thanks to John Burke. John Dorner, George Pindroh, and Bill Richardson for making this report possible.

\section{REFERENCES}

1. E.D. Walker and H.A. Slater, "Performance of Multimirror Quartzline Lamps in HighPressure Environments," NASA TM-83793, 1984.

2. E.D. Walker and H.A. Slater, "Method of Reducing Temperature in High-Speed Photography," NASA TM-83620, 1984. 
3. R.C. Hendricks and K.J. Baumeister, "Lighting in Cryogenic and Noncryogenic Fluids," NASA TM X-1654, 1977 .

4. "General Electric Photographic Lamp and Eq'ilpment Guide," 1988.

Table 1. Multimircor Quartzline Lamps For Large Format Applications

\begin{tabular}{|c|c|c|c|c|c|c|c|c|}
\hline $\begin{array}{l}\text { Lamp } \\
\text { code }\end{array}$ & Watts & $\underset{V}{\text { Rated, }}$ & $\begin{array}{l}\text { Average } \\
\text { rated } \\
\text { life. } \\
\text { hr }\end{array}$ & Filament & $\begin{array}{c}\text { Approximate } \\
\text { color } \\
\text { terperature. } \\
\mathrm{K}\end{array}$ & Base & $\begin{array}{l}\text { Approximate } \\
\text { beam spread }\end{array}$ & $\begin{array}{l}\text { Average } \\
\text { footcandle } \\
\text { at } 100 \mathrm{~cm}\end{array}$ \\
\hline $\begin{array}{l}\text { EPZ } \\
\text { DJT } \\
\text { DDM } \\
\text { DDS } \\
\text { DED }\end{array}$ & $\begin{array}{l}50 \\
50 \\
80 \\
80 \\
85\end{array}$ & $\begin{array}{l}13.8 \\
13.8 \\
19 \\
21 \\
13.8\end{array}$ & $\begin{array}{r}1000 \\
1000 \\
50 \\
1000 \\
1000\end{array}$ & $\begin{array}{c}\mathrm{CC}-6 \\
\end{array}$ & $\begin{array}{l}3150 \\
3150 \\
3300 \\
3125 \\
3125\end{array}$ & 2-pin & Natrow beam & $\begin{array}{r}a_{600} \\
800 \\
2800 \\
1500 \\
2000\end{array}$ \\
\hline $\begin{array}{l}\text { EPT } \\
\text { ENL. }\end{array}$ & $\begin{array}{l}42 \\
50\end{array}$ & $\begin{array}{l}10.8 \\
12\end{array}$ & $\begin{array}{l}8000 \\
1500\end{array}$ & $\mathrm{CC}-6$ & $\begin{array}{l}2900 \\
3050\end{array}$ & 2-pin & $\begin{array}{l}\text { Medium beam } \\
20^{\circ} \text { to } 30^{\circ}\end{array}$ & $\begin{array}{r}\mathrm{b}_{100} \\
150\end{array}$ \\
\hline $\begin{array}{l}\text { DDK } \\
\text { EPX }\end{array}$ & 80 & 19 & 40 & & 3300 & & & 600 \\
\hline $\begin{array}{l}\text { EPX } \\
\text { ESD }\end{array}$ & $\begin{array}{r}90 \\
150\end{array}$ & $\begin{array}{l}14.5 \\
120\end{array}$ & $\begin{array}{r}500 \\
12\end{array}$ & $c:-B$ & 3150 & oval $\frac{1}{2}$-pin & & $\begin{array}{r}640 \\
-\end{array}$ \\
\hline ELD/EJN & 150 & 21 & 10 & $\mathrm{CC}-6$ & 3350 & 2-pin & & 700 \\
\hline EJL & 200 & 24 & 50 & 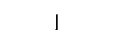 & 3400 & 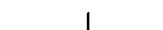 & & 550 \\
\hline EKX & 200 & 24 & 50 & & 3400 & & & 800 \\
\hline ELC & 250 & 24 & 50 & & 3400 & & & 750 \\
\hline ENH & 250 & 120 & 175 & $\mathrm{CC}-8$ & 3250 & Oval 2-pin & & 1000 \\
\hline ELH & 300 & 120 & 35 & $\mathrm{CC}-8$ & 3350 & Oval 2-pill & & 8000 \\
\hline ENG & 300 & 120 & 15 & $\mathrm{CC}-8$ & 3450 & Ova] 2-pill & & 11000 \\
\hline ERV & 340 & 36 & 75 & $\mathrm{CC}-8$ & 3300 & Oval 2-pin & $\begin{array}{c}\text { Broad beam } \\
-45^{\circ}\end{array}$ & $\begin{array}{r}C 900 \\
850\end{array}$ \\
\hline ENX & 360 & 82 & 75 & $\mathrm{CC}-8$ & 3300 & Oval 2-pin & & \\
\hline
\end{tabular}

Center beam.

beasured over a $1 \mathrm{ft}^{2}$ area.

cMeasured over a $2 \mathrm{tt}^{2}$ area.

Table 2. Test Results for Individual

ELH Lanips

\begin{tabular}{|c|c|c|c|}
\hline Lamp & $\begin{array}{c}\text { Pressure, } \\
\text { psi }\end{array}$ & $\begin{array}{l}\text { I'lame, } \\
\text { sec }\end{array}$ & Condition \\
\hline \multirow[t]{2}{*}{1} & $\begin{array}{l}3500 \\
4000\end{array}$ & 30 & $\mathrm{NF}^{\mathrm{a}}$ \\
\hline & 4500 & & \\
\hline \multirow[t]{3}{*}{2} & 3500 & & \\
\hline & 4000 & & \\
\hline & 1500 & 60 & \\
\hline \multirow[t]{3}{*}{3} & 3500 & 30 & \\
\hline & 4000 & 30 & \\
\hline & 4500 & 120 & \\
\hline \multirow[t]{3}{*}{4} & 3500 & 30 & \\
\hline & 4000 & 30 & \\
\hline & 4500 & 180 & \\
\hline \multirow[t]{3}{*}{5} & 3500 & 30 & \\
\hline & 1000 & 30 & \\
\hline & 4500 & 210 & \\
\hline \multirow[t]{3}{*}{6} & 3500 & 30 & \\
\hline & 4000 & 30 & \\
\hline & 4500 & 300 & \\
\hline \multirow[t]{4}{*}{7} & 3500 & 30 & \\
\hline & 4000 & 30 & \\
\hline & 1500 & 30 & \\
\hline & 5000 & 300 & $\mathrm{~F}^{\mathrm{b}}$ \\
\hline \multirow[t]{4}{*}{ B } & 3500 & 30 & $\mathrm{NF}$ \\
\hline & 1000 & 30 & $\mathrm{NF}$ \\
\hline & 1500 & 30 & $\mathrm{NF}$ \\
\hline & 5000 & 300 & $\mathrm{E}$ \\
\hline \multirow[t]{4}{*}{9} & 3500 & 30 & $\mathrm{NF}$ \\
\hline & 4000 & 30 & \\
\hline & 4500 & 30 & \\
\hline & 5000 & 300 & \\
\hline \multirow[t]{4}{*}{10} & 3500 & 30 & \\
\hline & $\$ 000$ & 30 & \\
\hline & 4500 & 30 & \\
\hline & 5000 & 300 & \\
\hline \multirow[t]{4}{*}{11} & 3500 & 30 & \\
\hline & 4000 & 30 & \\
\hline & 4500 & 30 & \\
\hline & 5000 & 300 & 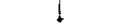 \\
\hline
\end{tabular}

$a_{\text {No }}$ failure.

${ }_{\mathrm{Faj}}$ ilure 


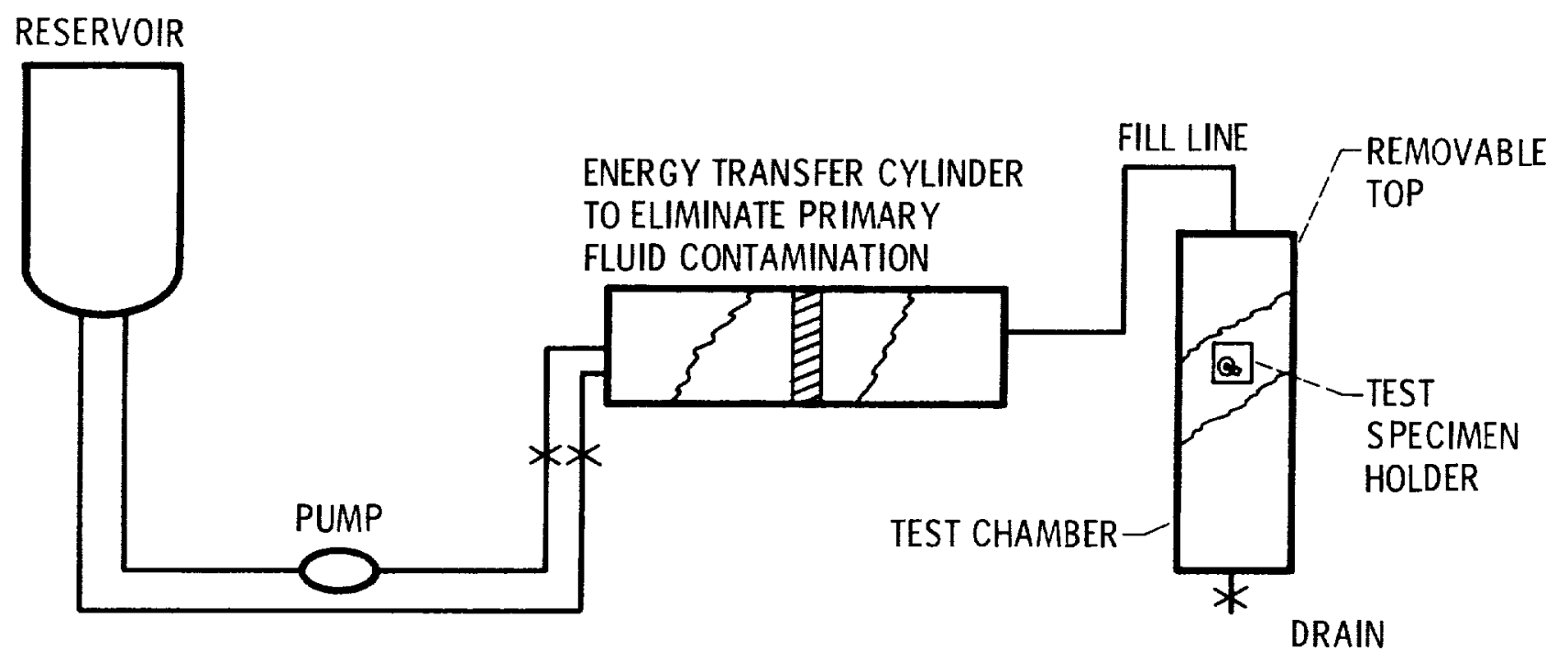

Figure 1. - High-pressure test facility. 
ORIIIRALL PACE IS

OF POOR QUALITY

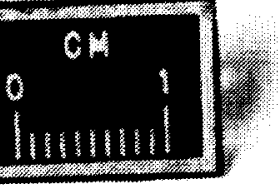

Figure 2. - ELHE MR-16 Q lamp. 


\section{ORIGINAL PAGE IS \\ OF. POOR QUALTY}

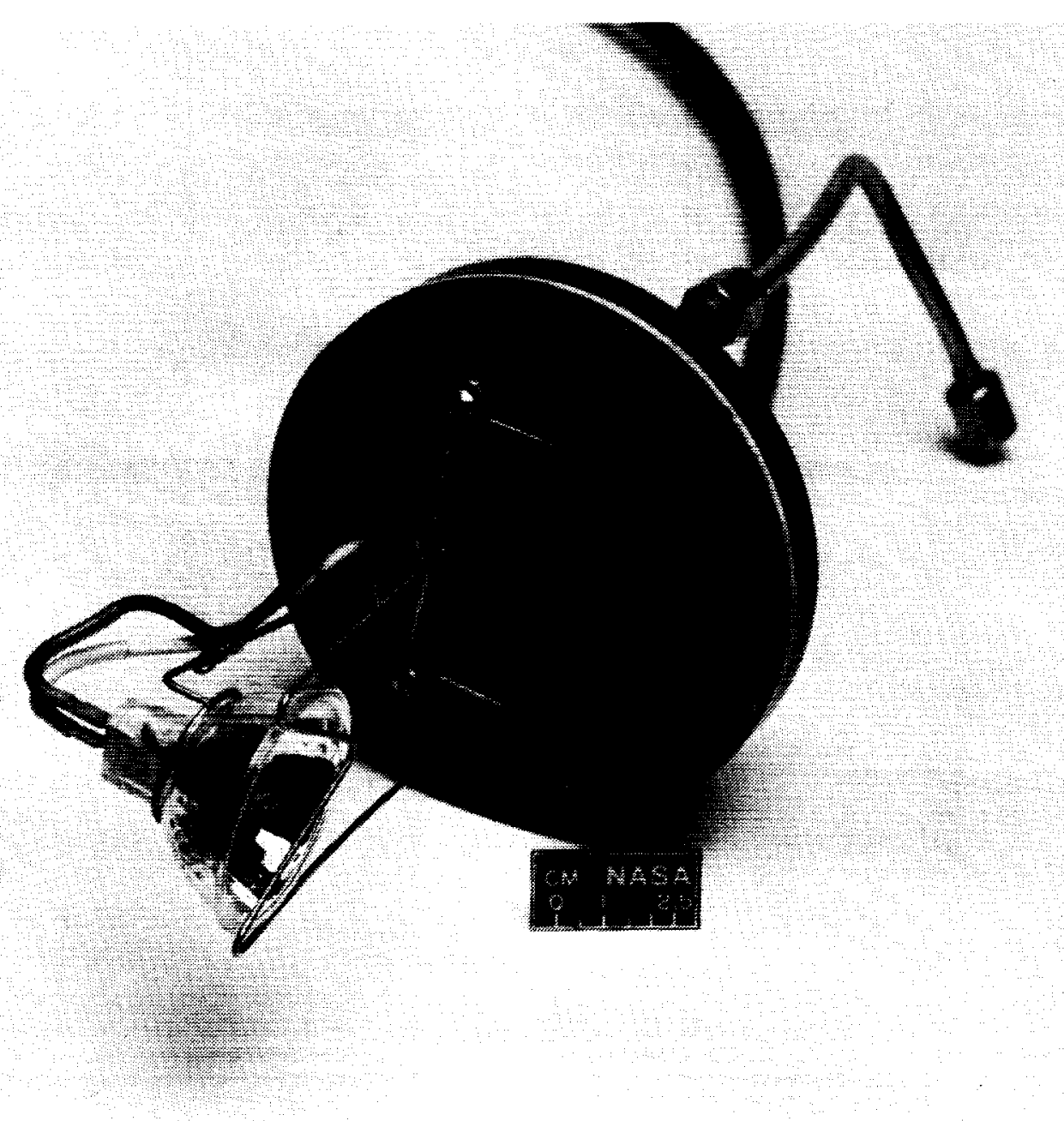

Figure 3. - Manufacture lamp support device. 


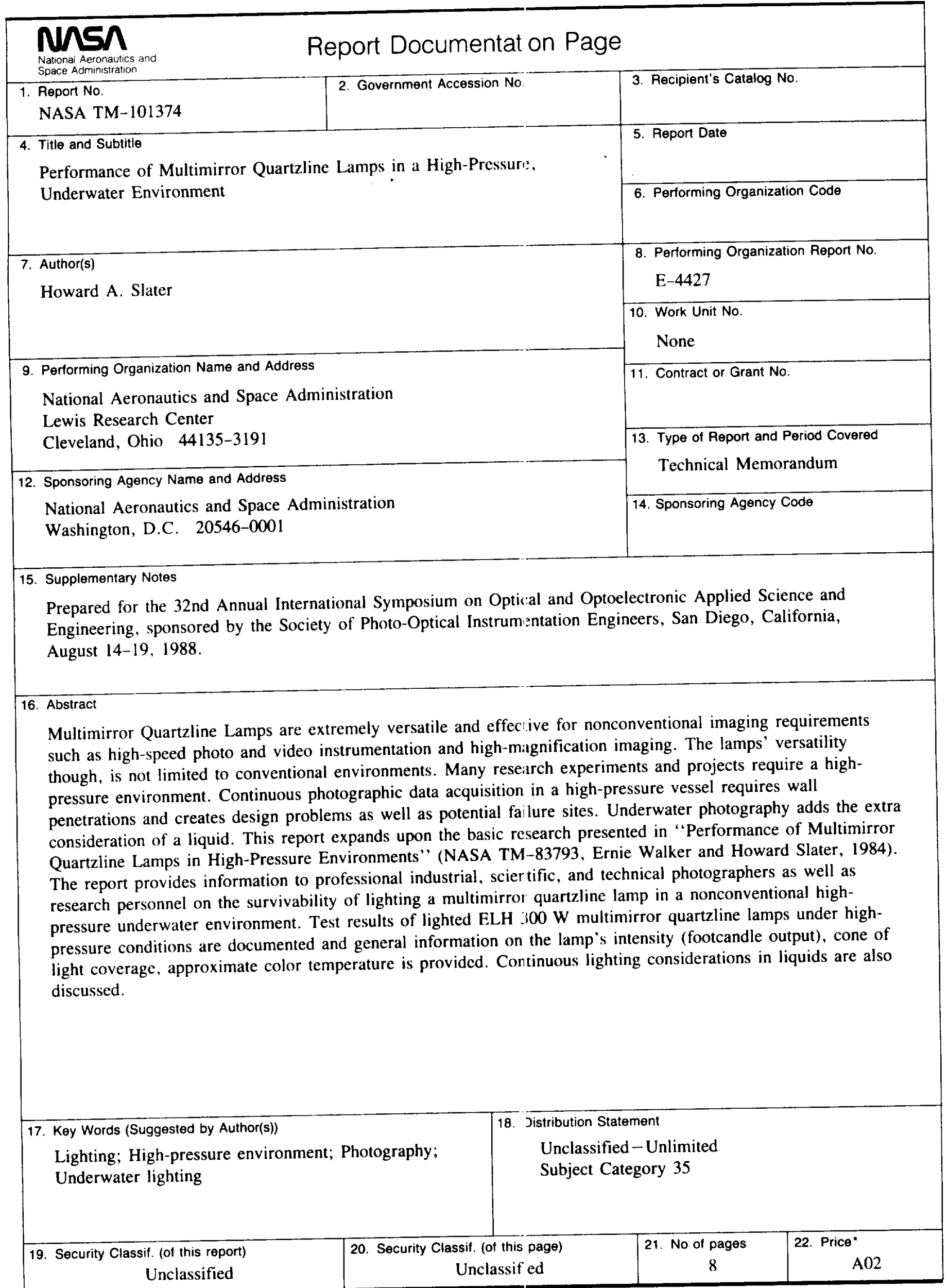


